\title{
Powerful remnants? The politics of egalitarian bargaining institutions in Italy and Sweden
}

\author{
Rebecca J. Oliver* \\ Department of Political Science, Miami University, Oxford, OH, USA

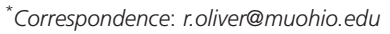

Why are some countries better able to sustain egalitarian outcomes attained in past decades in the current inhospitable conditions? Moreover, why have egalitarian practices proven fragile in some countries with traditionally strong social democratic governments and powerful unions and yet have been sustained in countries with disjointed unions and right-wing parties in power? Italy and Sweden, the central cases examined in this paper, reflect these diverging trends. In view of understanding why certain countries better sustain egalitarian institutions and outcomes, the paper investigates how two inter-related institutional traits set countries apart in terms of how egalitarian institutions were constructed and dismantled and how these traits influenced the type of institutional remnants and bargaining dynamics maintained in the aftermath. The two traits in question are: (a) the type of confederal groupings and; (b) the range of wage scale coverage.

Keywords: inequality, institutional change, labor market institutions, low-wage employment, trade unions, Europe

JEL classification: J31 wage level and structure, wage differentials

\section{Introduction}

The time when multiple labour unions and governments across Western Europe implemented categorically egalitarian policies, which fundamentally lowered pay differentials between workers of different skill levels appears to be over. Global economic competition, major innovations and technological advances in production techniques have weakened the demand for lower skilled workers across advanced industrial democracies (Berman et al., 1994; Wood, 1995). In this context, the entire array of egalitarian wage bargaining institutions appears to be experiencing overwhelming duress.

It is becoming clear that even countries characterized as 'coordinated market economies', well known for exhibiting the opportune combination of more equal 
income distribution and strong economic growth (Kenworthy, 2004; Pontusson, 2005), are not exempt from the major global changes taking place. Instances of faltering egalitarian wage bargaining arrangements are well documented (Pontusson and Swenson, 1996; Kitschelt and Streeck, 2003). However, not all countries are experiencing a similar retreat of egalitarian measures (Rueda and Pontusson, 2000; Pontusson, 2005; Kenworthy, 2008).

Why are some countries better able to sustain egalitarian outcomes attained in past decades in the current inhospitable conditions? Moreover, why have egalitarian practices proven fragile in some countries with traditionally strong social democratic governments and powerful unions and yet have been sustained in countries with disjointed unions and right-wing parties in power? Italy and Sweden, the central cases examined in this paper, reflect these diverging trends. Both have had strong, widespread egalitarian policies in the past and yet their developments in wage bargaining institutions have taken very different paths, which stand in stark contrast to conventional views held about each case. Sweden is known for its powerful and well-organized unions, with among the highest membership levels in the world (Kjellberg, 1992). On the other hand, the Italian labour movement is often characterized as being weakly institutionalized and severely fragmented (Cella, 1989). In the absence of widespread actively egalitarian bargaining institutions (post-1983 for Sweden and post-1992 for Italy) both countries have experienced some increased wage inequality among full-time workers. ${ }^{1}$ Yet changes in Sweden have been more pronounced and arrangements in Italy appear to have been better able to prevent a marked increase in wage differences, as illustrated in Figure 1, drawn from the OECD 'Structure of Earnings' data set based on gross earnings of full-time employed individuals by earnings deciles (OECD, 2002). ${ }^{2}$

Although the number of years of available data in the post-egalitarian period is rather limited in Italy, one may still note that the percentage of an average annual change is consistently less pronounced in Italy than in Sweden. The different trajectories are illustrated in greater detail in Table $1 .{ }^{3}$ In the case of Italy, the data

\footnotetext{
${ }^{1}$ Union coverage has in fact remained high for these workers: between 89 and $92 \%$ in Sweden and $82 \%$ in Italy (Visser and Checchi, 2009, p. 36).

${ }^{2}$ These data have been published (OECD, 2004) and used in a number of cross-national studies focused on changes in inequality over time (Wallerstein, 1999; Kenworthy and Pontusson, 2005; Visser and Checchi, 2009).

${ }^{3}$ Unlike wage inequality, Italy's post-transfer income inequality appears to have risen more substantially than in the Swedish case according to data on net income from Survey of Household Income and Wealth (SHIW) from Bank of Italy (Brandolini et al., 2001; Atkinson, 2008). The relationship between changes in the distribution of wages and the redistribution of income is examined in Kenworthy and Pontusson (2005) and Kenworthy (2008). Data on net income (SHIW) differ in a number of respects from the INPS data presented here, notably in that the SHIW includes income data for part time workers and workers that may only work a portion of the year.
} 


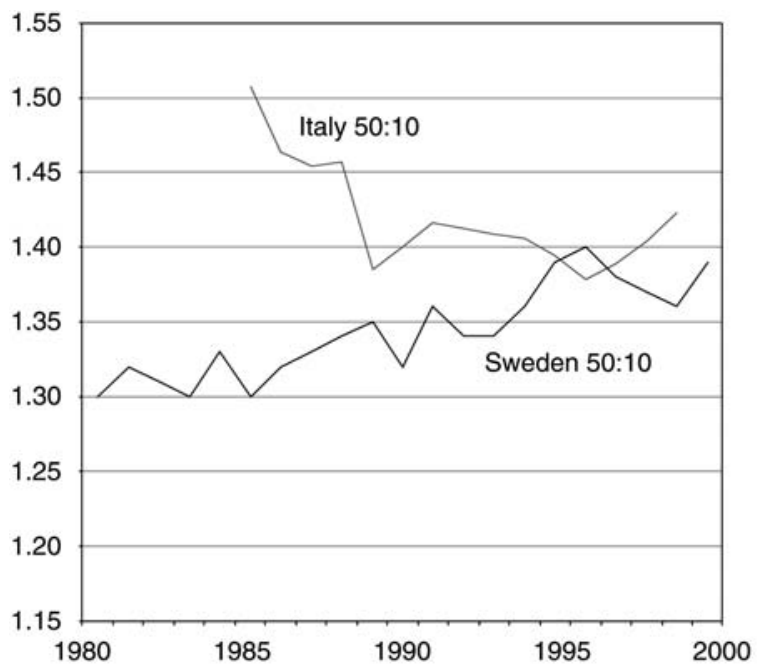

Sources: Sweden, OECD Wage Earnings Dataset; Italy, OECD Wage Earnings Dataset and INPS, data accessed at Laboratorio R. Revelli, Centre for Employment Studies, Turin, March 2003.

Figure 1 Earnings inequality (50:10) in Italy (1985-1998) and Sweden (1980-2000).

Table 1 Increase in 90:10 earnings ratio, post-egalitarian institutions (Italy, 1992-1998 and Sweden, 1983-2000)

\begin{tabular}{llrr}
\hline & & Sweden & Italy \\
\hline \multirow{2}{*}{ 50:10 ratio } & Level in final year with widespread egalitarian bargaining & 1.30 & 1.41 \\
& Average annual change & 0.53 & -0.15 \\
90:10 ratio & Level in final year with widespread egalitarian bargaining & 1.95 & 2.17 \\
& Average annual change & 2.35 & 1.14 \\
90:50 ratio & Level in final year with widespread egalitarian bargaining & 1.50 & 1.69 \\
& Average annual change & 1.12 & 0.73 \\
\hline
\end{tabular}

Notes: The 90:10 ratio is the only earnings inequality ratio that includes government and private sector workers for both Italy and Sweden. In the other earnings ratios, the Italian data do not include government workers. For Sweden, Average Annual Change: (90:10 for 2000-90:10 for 1983)/Number of Years Covered, multiplied by 100. For Italy, Average Annual Change: (90:10 for 1998-90:10 for 1992)/Number of Years Covered, multiplied by 100; more details in Data Appendix.

Source: Sweden, OECD Wage Earnings Dataset; Italy, Istituto Nazionale della Previdenza Sociale, INPS) accessed at Laboratorio R. Revelli, Centre for Employment Studies.

within the OECD database drawn from Italian National Social Security Institute (Istituto Nazionale della Previdenza Sociale, INPS) excludes government workers. However, with direct access to the INPS data, it was possible to re-calculate the 90:10 ratios with government workers. ${ }^{4}$ Wage differences may be over-

\footnotetext{
${ }^{4}$ Details in the data appendix.
} 
represented by the 90:50 and 50:10 ratios due to the fact that the available data exclude government sector workers, a sector where wages tend to be highly regulated and the wage distribution relatively compressed and stable over time (Wallerstein, 1999).

In view of understanding why certain countries better sustain egalitarian institutions and outcomes, this paper investigates how two inter-related institutional traits set countries apart in terms of how egalitarian institutions were constructed and dismantled and how these traits influenced the type of institutional remnants and bargaining dynamics maintained in the aftermath. The two traits in question are: (a) the type of confederal groupings and (b) the range of wage scale coverage.

The form of confederal grouping refers to the lines along which union confederations are organized, either according to occupational type (blue-collar, whitecollar, professional) or another criterion that aggregates high-skilled and lowskilled workers such as religious or ideological affiliation. Like political party systems, which reflect a number of different types of cleavages, union confederations may be organized along a number of different lines, depending on the force of political or religious cleavages and the sequencing of developments. ${ }^{5}$ Figure 2 illustrates these two organizational patterns.

The second trait, the type of wage scales, refers to whether wage negotiations in a given industry utilize a systematic categorization of different skill-levels with specified minimum pay levels (wage scales, wage minima). In other words, do wage negotiations in a given industry involve industry-wide wage scales? If so, are such scales elaborated for only blue-collar workers, for white- and blue-collar workers in separate scales or for white- and blue-collar workers in a common scale? Table 2 illustrates the differences in the coverage of wages scales in the metalworking sector in Italy and Sweden.

As the cases of Italy and Sweden demonstrate, the type of wage scales and confederal groupings are closely intertwined. If separate confederations exist for blue- and white-collar workers, there tend not to be common wage scales. In cases with one major union confederation, there may be separate wage scales, as in Austria or Germany prior to 2002.

Operating conjunctively, the particular form of wage scales and conferedal groupings influences how different union confederations relate to one another, the ways in which debates about wage dispersion take place, the actual mechanisms for calculating wage increases and the coverage of negotiations. Early on, these two institutional characteristics impacted how ideas about solidarity and equality were formulated. Later, they shaped the form of protest and the type

\footnotetext{
${ }^{5}$ Visser and Waddington (1996) provide detailed analyses of the origins of union confederations. Ingham (1974) investigates links between industrial structure and unions.
} 
Sweden

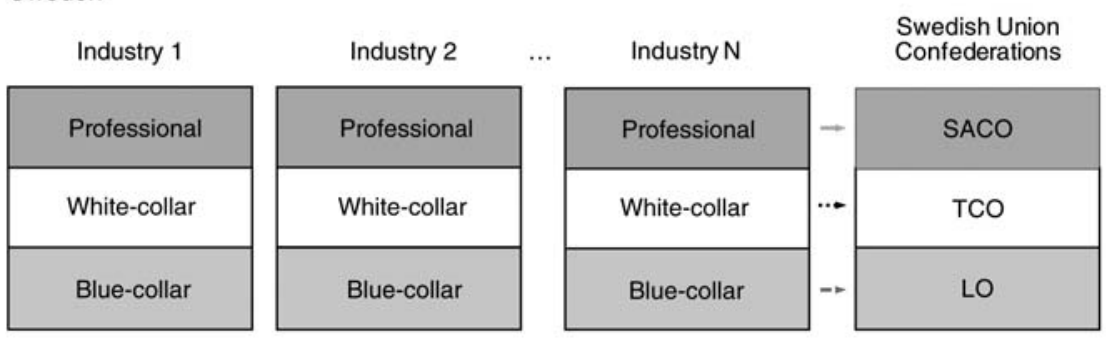

Italy

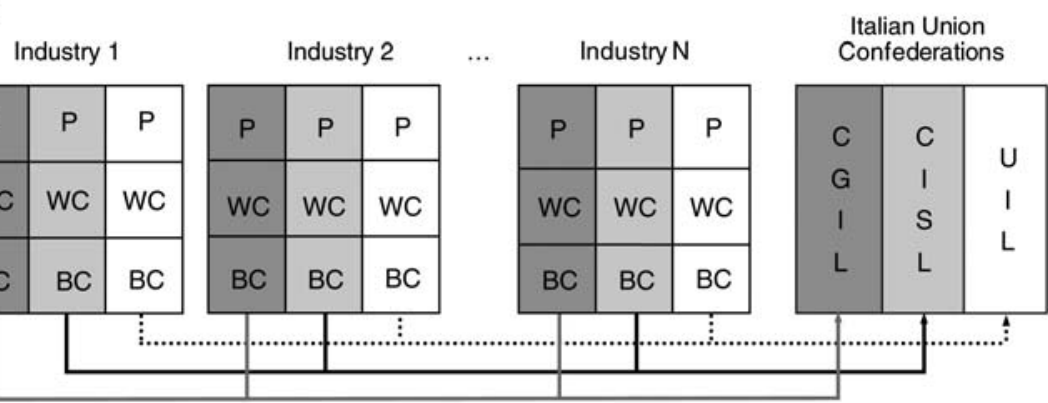

Notes: $\mathrm{BC}=$ Blue-collar workers; $\mathrm{WC}=$ White-collar workers; $\mathrm{P}=$ Professional workers .

Figure 2 Confederal groupings in Sweden and Italy.

Table 2 Wage scales in Italy and Sweden (metalworking sector)

\begin{tabular}{|c|c|c|c|}
\hline \multicolumn{2}{|l|}{ Italy } & \multicolumn{2}{|l|}{ Sweden } \\
\hline $\begin{array}{l}\text { Wage scale } \\
\text { category }\end{array}$ & $\begin{array}{l}\text { Composition of wage } \\
\text { scale category }\end{array}$ & $\begin{array}{l}\text { Wage scale } \\
\text { category }\end{array}$ & $\begin{array}{l}\text { Composition of wage } \\
\text { scale category }\end{array}$ \\
\hline Level 7 Quadri & Professional/white-collar & No wage scales & Professional \\
\hline Level 7 & Majority white-collar & No wage scales & White-collar \\
\hline Level 6 & White-collar and blue-collar & Level 4 & Blue-collar \\
\hline Level 5 & White-collar and blue-collar & Level 3 & Blue-collar \\
\hline Level 4 & White-collar and blue-collar & Level 2 & Blue-collar \\
\hline Level 3 & White-collar and blue-collar & Level 1 & Blue-collar \\
\hline Level 2 & Majority blue-collar & & \\
\hline Level 1 & Majority blue-collar & & \\
\hline
\end{tabular}

of coalitions that emerged to counter declining wage dispersion, and, consequently, the emerging process of dismantling egalitarian institutions. The degree to which remnants of past egalitarian institutions were carried forward was contingent on both the form of the previous institutions and the politics 
of dismantlement. In the wake of the era of actively egalitarian institutions, wage scales and conferedal groupings continue to shape debates about inequality, the goals of union leaders and the expectations of union members.

The remainder of the paper proceeds in four sections. Section 2 contextualizes the current research within debates about bargaining institutions and inequality. In Section 3, the type confederal groupings and wage scales are described in detail for the cases of Italy and Sweden. In Section 4, I examine developments in Italy and Sweden during the construction of egalitarian policies and their dismantling. Section 5 outlines the bargaining practices in the current period and underscores the remaining institutional traits that have stabilized wage differences in each case. Section 6 concludes.

\section{Existing research}

The overarching topic of this paper, wage bargaining institutions and inequality, has received considerable attention within the literature. More precisely, a number of cross-national studies have examined how a country's particular form of collective bargaining institutions impacts the overall level of inequality among full-time wage earners at a given moment in time (Koeniger et al., 2007; Checchi and García-Peñalosa, 2008). Overall, the most consistent explanatory factor has been the level of centralization of wage bargaining (Bardone et al., 1998; Iversen, 1999; Wallerstein, 1999; Pontusson et al., 2002; Pontusson, 2005). As scholars within this field note, it is important to recognize that centralized bargaining does not inherently involve solidaristic or egalitarian wage bargaining, as it is entirely possible 'to write general rules for pay raises that do not compress relative wages' (Wallerstein, 1999, p. 673). Indeed, centralized bargaining may lead to a wide range of wage rules, not all of them egalitarian.

There have been a number of important studies closely investigating changes over time to labour market institutions. Much of this body of work has concentrated on changes in the level of centralization of bargaining and the rise of decentralization of wage bargaining practices (Katz, 1993; Thelen, 1993; Iversen, 1996; Pontusson and Swenson, 1996; Traxler et al., 2001) or the re-emergence of centralized framework arrangements and social pacts between centralized employer and labour institutions (Pérez, 2000; Regini, 2000; Baccaro, 2003; Molina and Rhodes, 2007; Natali and Pochet, 2009). This work has shed light on the underlying logics of institutional change and the complexity related to the levels of collective bargaining and the process of concertation; it has not however tended to focus on the specific aspects of bargaining institutions that stabilize skill-based wage differentials.

Research has yet to resolve which factors explain why in some countries, which have had extensive egalitarian institutional structures in the past, wage bargaining institutions have eroded or been dismantled, whereas in other countries such 
institutions are more stable with key institutional remnants carried forward from previous institutional settings. In order to better understand differences in the development and resilience of egalitarian bargaining arrangements and wage inequality among full-time dependent workers, this paper argues that we need to focus on specific aggregational traits of wage bargaining (i.e. how are high-/low-skilled workers organized?) and elements of the bargaining content (i.e. what precisely is being negotiated at the central level, are distributional parameters included?).

\section{Confederal groupings and wages scales in Italy and Sweden}

\subsection{Confederal groupings}

In Italy, early splits from the single post-war union confederation meant that union confederations were divided according to ideological or confessional affiliation. In June 1944, a single union confederation, Confederazione Generale Italiana del Lavoro, (CGIL) was founded through an agreement known as the Pact of Rome, which was signed by coalition leaders from Communist, Socialist and Catholic political parties, who had been united during the Second World War in the Resistance movement. In 1948, union unity was ruptured. Several leaders created a new union confederation, which, after merging with two smaller autonomous organizations, became the Confederazione Italiana dei Sindacati Lavoratori (CISL). The CISL has been characterized as a Catholic, anti-communist union with a 'social Christian' philosophy and links to the former Christian Democratic party (Lange et al., 1982; Golden, 1988). The CISL's perspective on union activity was that the union should 'act as an association of its members (not as an agent of the working class as a whole)' (Lange et al., 1982, pp. 114-115). The CISL refrained from defining itself in terms of political battles but rather emphasized the importance of collective bargaining and the 'logic of autonomous union action' (Cella et al., 1977, p. 35), ${ }^{6}$ as apposed to political action.

In the same year, a further split occurred within the CGIL. Leaders of the Social Democratic and Republican currents within the CGIL broke off to form a new union confederation, the Unione Italiana del Lavoro (UIL) (Baglioni, 1980). The UIL is more easily described in opposition to the other two larger confederations, and has sought to 'maintain a position equally distant from what it considered to be the Communist union and what it defined as a pro-government union' (Lange et al., 1982, p. 116). The three main union confederations thus established slightly different political stances and each held important ties with at least one political party [in the 1980s, up to $60 \%$ of members of the CGIL were also members of the Communist Party (PCI)], (Golden, 1988) though such ties are less apparent today, due in part to changes in the party system (Visser, 2000).

\footnotetext{
${ }^{6}$ Translated and paraphrased by the author.
} 
In Sweden, union confederations were formed along white- and blue-collar lines. The central blue-collar confederation, the Swedish Federation of Trade Union (Landsorganisationen i Sverige, LO) was founded in 1898. From its early years, the LO promoted 'working class solidarity' by including unskilled bluecollar workers within the organization, as opposed to focusing on skilled or semiskilled blue-collar workers (Ebbinghaus and Visser, 2000). The LO chose to restrict the admission of white-collar workers, though its close political ties with the Social Democratic Party (SAP) also contributed to the creation of separate white-collar organizations as these new organizations sought to establish a measure of independence from the SAP (Kjellberg, 1998; Visser, 2000). By 1944, one of the main white-collar organizations, TCO (Tjänstemännens Centralorganisation), was created through a merger of existing unions. One of the original explicit goals of the TCO was to 'represent interests of the white-collar workers vis-à-vis the government and other organizations' (De Geer, 1992, p. 103). A few years later, in 1947, a union confederation for professionals or university degree holders was founded: the Swedish Federation of Professional Associations (Sveriges Akademikers Centralorganisation, SACO).

\subsection{Wage scales}

In Italy, minimum pay levels for a given qualification level stem from historic corporatist collective agreements, concluded as part of the legal framework that instituted the Fascist corporatist regime. In 1944, the corporatist system was abolished. Nonetheless, the corporatist collective agreements were maintained. From the immediate post-war period onwards, nationally centralized agreements and later sectoral agreements laid out detailed skill-categorization levels and equivalent pay minima for each level (inquadramento), for both blue- and whitecollar workers. The skill-level categories of the early national contracts replicated categories established by earlier corporatist collective agreements (Carinci, 1987). These scales were carried forward as part of a strategy to pursue low-wage costs (Locke and Thelen, 1995) and lessen factory protests and unrest on the plantfloor: Confindustria, the main employers' association, sought to establish 'wage agreements at a national level, which excluded the possibility of local or factory agitation' (Ginsborg, 1990, p. 95). In 1972, white- and blue-collar industry-wide wage scales were merged across industries, beginning with the metalworking sector.

In Sweden, there have not been common wage scales for all skill-level categories but rather only for blue-collar workers. ${ }^{7}$ Wage agreements for blue-collar workers include what are called 'basic wage rates', which are based on fairly

\footnotetext{
${ }^{7}$ Until the 1990s, banks and insurance companies did have industry-wide wage tariffs (Edgreen, 1966; Kjellberg, 2004).
} 
rudimentary criteria such as the presence or absence of any training or apprenticeship. The rates are only used to determine differences in the basic starting wage and not for differentiating wage increases. As long as a worker's wage is higher than the minimum basic rate set for their pay category, wage scales play very little role in collective bargaining negotiations.

Swedish employers strongly opposed any form of wage scales for white-collar workers. In the early 1950s, the Swedish Employers' Federation (Svenska arbetsgivareföreningen, SAF) elaborated a more specific policy for white-collar workers, whereby, (a) there would not be wage scales in collective agreements for white-collar workers; and (b) the SAF could formulate general recommendations with regard to the size of the average wage increase. The idea was that, 'white-collar workers were to be treated in such a way that their primary loyalty would be to their companies, and their higher ranks should remain nonunionized' (De Geer, 1992, p. 104). The absence of wage scales for salaried employees has been described as a key victory of employers (De Geer, 1992) and employer opposition to such scales is well documented (Kjellberg, 2004). Furthermore, many white-collar unions fervently opposed the inclusion of 'difficulty grading' in the job classification system (Swenson, 1989, p. 155). According to a former director of the employers' association: 'every draft [of the job evaluation scheme] which has leaked out to the public has met with violent protestsparticularly from white-collar unions' (Myrdal, 1991, p. 200).

\section{Actively egalitarian institutions}

\subsection{Egalitarian institutions in Italy}

High levels of wage equality were not reached in Italy until the 1970s. In general, wages were quite low during the decades immediately following the war, rising at a slower pace than productivity. However, this trend began to change after the series of widespread strikes and protests initiated in 1969, known as 'Hot Autumn' (autunno caldo). During this period, the mobilization of workers appeared limitless and unions initiated a phase of wage militancy focusing on the situation of the operai communi [common manual labourers] (Accornero, 1992).

In 1969, within the context of the 'Hot Autumn', bargaining platforms for industry-level contracts (CCNL) were modified, first within the metalworking sector and then throughout all sectors. The new course of action was to include equal flat-rate wage increases for workers of all skill-level categories. The change was controversial. In fact, the FIOM (Federazione Impiegati Operai Metallurgici), the metalworking branch of the CGIL confederation was originally opposed to such a change and preferred to maintain wage increases in line with 
the parametric scale, whereas FIM (Federazione Italiana Metalmeccanici), a branch of the CISL, favoured it. The FIOM's goal was rather that all workers attain higher pay and rewarding work through training and skill development (Regalia et al., 1978). It sought an egalitarian shift at the shop floor through the development of 'potentially equal jobs-equal in the sense of being more or less engaging, flexible and knowledge intensive' (Baccaro and Locke, 1996, p. 22). The FIM, on the other had a simpler egalitarian view, centred on ideas emerging from its Catholic heritage emphasizing that humans are all fundamentally equal and that work is merely a means to existence, thus advocating greater equality in pay regardless of skill and, in this case, 'aumenti uguali per tutti (a flat-rate increase for everybody)' (Baccaro and Locke, 1998, p. 299). In the end, the FIM and FIOM agreed to consult workers on the question and the outcome was to pursue an equal flat-sum increase, equal for all workers in the contract renewal of 1969 (Carniti, 1977). Although the practice of flat-rate wage increases at the industry level was not institutionalized in any manner, it had an important impact on wage distribution for the years in which it was carried out, from 1969 to the late 1970s (Faustini, 1976; Dell'Aringa, 1994).

The second egalitarian measure was initiated during the 1972 contract renewal negotiations in the metalworking sector, when union representatives demanded a new single skill-level classification scheme for both white- and blue-collar workers (inquadramento unico) with a total of only five skill-level categories (Bedani, 1995, p. 170). Negotiations were long and difficult. In the end, the contract established a new integrated wage scale for blue- and white-collar workers with seven categories, reducing the number of categories considerably. Shortly after the metalworking contract was signed, in 1973, contracts in other industries integrated a unified scale as well.

The idea behind the pursuit of the inquadramento unico was not simply to reduce wage differences between workers of different skill levels. Rather, it was a means to overcome the division between manual and intellectual work (Begamaschi et al., 1980). Such changes were also part of a wider debate about solidarity, Golden (1988, p. 120) explains:

[i]n battling an anachronistic system of job classification, semi skilled workers, argued the FLM, ${ }^{8}$ would draw a more general lesson concerning the importance of unity and solidarity and, eventually, would extend the lessons from the shop floor to political battles against equally anachronistic and oppressive conditions in society at large.

Finally, the most well-known egalitarian provision within collective bargaining in Italy occurred when the scala mobile, the automatic indexation mechanism,

\footnotetext{
${ }^{8}$ Joint body of metalworking federations, including FIOM, FIM and UILM.
} 
Table 3 Wage developments: metalworking Industry in the region of Milan

\begin{tabular}{|c|c|c|c|c|c|c|}
\hline \multirow[b]{2}{*}{ Wage-category } & \multirow[b]{2}{*}{$\begin{array}{l}\text { Type of } \\
\text { occupation }\end{array}$} & \multirow{2}{*}{$\begin{array}{l}\text { Increase in contrac- } \\
\text { tual minima as \% of } \\
\text { total wage } \\
1995\end{array}$} & \multicolumn{4}{|c|}{ Total wage increases (\%) } \\
\hline & & & $\begin{array}{l}1994- \\
1995\end{array}$ & $\begin{array}{l}1996- \\
1997\end{array}$ & $\begin{array}{l}1999- \\
2001\end{array}$ & Average \\
\hline Level 7Q & Quadri & 1.25 & 0.8 & 2.5 & 5.9 & 3.1 \\
\hline Level 7 & White-collar & 1.58 & 0.9 & 3.2 & 6.4 & 3.5 \\
\hline \multirow[t]{2}{*}{ Level 5} & White-collar & 2.04 & 2.8 & 2.7 & 4.7 & 3.4 \\
\hline & Blue-collar & 2.11 & 2.2 & 3.8 & 3.8 & 3.3 \\
\hline \multirow[t]{2}{*}{ Level 3} & White-collar & 2.23 & 2.6 & 2.4 & 3.0 & 2.7 \\
\hline & Blue-collar & 2.24 & 2.9 & 3.8 & 5.2 & 4.0 \\
\hline
\end{tabular}

Source: Assolombarda, the Milanese employers' association, affiliated with Confindustria.

previously introduced in post-war contracts of 1945 and 1946, was modified in 1975. Prior to this, the scala mobile increased wages in line with the increase in cost of a defined basket of goods and inflation increases were differentiating using skill-level categories within industry-wide collective bargaining agreements (Lungarella, 1981). In 1975, Confindustria and all three confederations signed an agreement that modified the nation-wide automatic indexation mechanism by introducing a single point system (punto unico di contingenza) in which every point increase in inflation led to an automatic flat-rate payment, equal for all workers. The amount paid was the equivalent of what the workers in the highest pay grade received as an indexation payment in 1974. The payments were to be added to wages automatically without any need for negotiation on the part of local or industry-wide union federations.

It was the employers' organization, Confindustria, led by Giovanni Agnelli (the president of Fiat from 1966 to 1996) that initiated talks for this modification to the indexation policy. Part of the motivation appears to have been to lower union conflict, especially at the firm or plant level. Since local level union organizations were generally more militant and strike prone than the confederal union organizations, the Confindustria sought to centralize key elements of wage bargaining in exchange for employment guaranties (Patriarca, 1986; Locke, 1995).

The combined effect of the agreement and sustained rates of inflation substantially lowered wage differences between high- and low-skilled workers to a degree that does not appear to have been anticipated by negotiators at the time (Erickson and Ichino, 1994). Inflation rose sharply in Italy over the next 10 years, hovering close to $20 \%$ for a number of years. As illustrated in Table 3, for the average worker in the industrial sector, the percentage of annual wage increases due to 
indexation payments rose substantially. For the average wage in the industrial section, indexation payments constituted 35\% of the total increase in 1974 and 64\% by 1981 (Patriarca, 1986, p. 196).

The late 1970s and early 1980s were marked by various signs of protest about the decline of wage differences between high- and low-skilled workers. A first sign of discontentment with egalitarian collective bargaining occurred in the late 1970s when new 'autonomous' organizations emerged to represent only high-skilled workers. Their main priority was to renew wage differentials between high- and low-skilled workers. However, these organizations did not appear to gain a substantial membership in the private sector. ${ }^{9}$ Finally, in a historic strike at Fiat, in October 1980, named the 'March of 40 000' (Marcia dei 40 000), foremen and highskilled workers protested that their interests were not adequately represented in negotiations (Bedani, 1995). However, aside from bringing the topic of wage differences to the fore, the strike did not actually impact bargaining practices.

In 1982, the Confindustria threatened to unilaterally cease its adherence to the 1975 accord. This action would have eliminated the large flat-rate indexation payments and indexation policy would have reverted to the more modest parameters laid out in a 1957 interconfederal settlement. However, instead, a series of negotiations over the specific calculation of scala mobile payments began in 1982. Although the positions of the three labour unions differed in these negotiations, at no point were employers able to coalesce with a grouping of disgruntled higher paid workers and break away from previous agreements. In 1983, employers, union confederations and the government signed an agreement (Accordo del 22 gennaio 1983), which aimed to reduce inflation to less than $10 \%$ by 1984 and address the unemployment problem. The agreement contained a number of provisions geared towards price stabilization. Only in 1986, was the egalitarian nature of indexation modified when the government passed a decree. The decree applied a solution to the inflation issue that had been previously agreed upon by employers' associations and union confederations but had not been formalized due to the intense conflict on other issues such as hours of work: it formally extended the public sector indexation mechanism to all workers in the private sector, which provided $100 \%$ coverage for a portion of wages (580 000 lire a month), whereas the remainder of a worker's wage was indexed at a rate of $25 \%$.

Although the Confindustria threatened again to unilaterally withdraw from the scala mobile indexation system, in 1990, complaining that the existing system added heavily to labour cost and had 'an excessive leveling effect on pay' (EIRR, 1990, p. 10), this threat was not carried out. The collective bargaining system was reformed 2 years later, following extensive tripartite negotiations focused on Italy's ability to satisfy the convergence criteria for the Economic

\footnotetext{
${ }^{9}$ Rather they had stronger numbers in the public sector (Baccaro et al., 2003).
} 
and Monetary Union (EMU). Changes were initiated in 1992 when the three main union confederations, the public and private employers' associations and the government (an interim government appointed by the President, due to the cloud of suspicion surrounding previous cabinet members) signed a tripartite agreement on inflation. The 1992 Protocol stated that parties agreed to the definitive cessation of the automatic indexation system (scala mobile). As Regini and Regalia (1997, p. 214) summarize:

the aim was to reduce the inflation rate ... The core of the agreement was therefore the curbing of wages growth without the compensatory measures that had accompanied the political trade-offs made in the early 1980s.

In 1993, the second tripartite agreement integrated cost-of-living payments within industry-wide wage bargaining contracts (CCNL), and maintained firmlevel negotiations for the allocation of productivity related wage increases, as described further in Section 5.

The 1992 and 1993 agreements marked the end of widespread actively egalitarian wage policies in Italy (Erickson and Ichino, 1994; Baccaro and Locke, 1998; Cella and Treu, 1998). Interestingly, debates surrounding the actual institutional reforms did not centre on skill-differentials, but rather on 'the degree of coverage and the reaction speed of the escalator' (Erickson and Ichino, 1994, p. 280). In the end, unilateral attempts by employers and high-skilled groups to reverse egalitarian trends were not carried out and considerable measures from the egalitarian period were integrated within new bargaining practices.

\subsection{Egalitarian institutions in Sweden}

In Sweden, wage equality surfaced as an issue of debate within the blue-collar confederation (LO) as early as 1936. However, it was not until 1951, that a key report was delivered to the LO Congress, Trade Unions and Full Employment, which initiated a new phase of wage policies known as the Rehn-Meidner model. A critical element of the model was a 'solidaristic' wage policy, one where workers performing similar tasks were rewarded with similar pay, regardless of the profitability of their firm or strength of their local union (Meidner and Ohman, 1972, p. 13). ${ }^{10}$

In the mid-1950s, the first set of solidaristic policies was implemented, these aimed to lower wage differences between workers of similar skill levels in different sectors. The policy entailed the coordination of wage increases between high- and low-paying sectors in the context of highly centralized bargaining, which took place between the LO and the peak-level employers' organization (SAF). Many

${ }^{10}$ Active labour market policies were also a key facet of the model (Molin et al., 1988). 
employers were favourable to the original idea, although not always explicitly (Swenson, 1991; Vartiainen, 1998). The central motivation of employers to engage in this initial form of solidaristic bargaining was that wage costs could be better controlled if one eliminated wage rivalries between sectors.

In the mid-1960s and in the early 1970s, the LO began to pursue more actively egalitarian policies targeted at improving the relative pay of lower-paid workers across all sectors. The 1964 national framework agreement included a flat amount designated to supplement the wages of the lowest-paid workers in each sector (low-wage pot or kitties).

Egalitarian policies were thus layered upon the existing institutional structures, which included separate union confederations for white- and blue-collar workers, rudimentarily developed blue-collar wage scales and the absence wage scales for white-collar workers. This meant that most early egalitarian provisions applied only to blue-collar workers. In a 1974 report, Co-ordination and Solidarity, Meidner (1974) provided a number of insights on the difficulties of exercising wage solidarity in such a context, noting in particular that without a job evaluation scheme, 'there was no other way of implementing the wages policy of solidarity than ... a simple striving for the elimination of all wage differentials, however caused' (pp. 40-41).

One of the factors that appeared to contribute to the lower levels of wage equality during the 1956-1965 period was the fact that, for the most part, the LO-SAF agreement was a 'starting point and a norm' (Olsson, 1991, p. 26) for white-collar private sector agreements. A few early white-collar agreements even included egalitarian provisions similar to those negotiated by the LO (Forsebäck, 1980; Jonsson and Siven, 1986; Kjellberg, 1992).

By the mid-1960s, white-collar organizations, ${ }^{11}$ having grown larger (Kjellberg, 1998, p. 646) asserted greater independence from the LO in negotiations and specifically sought to raise salaries relative to the wages of workers (Olsson, 1991, p. 114). Tensions between white-collar and blue-collar organizations grew after 1966 when LO-SAF national agreements introduced provisions called 'wage drift guarantee'. Wage drift refers to amounts received by employees over and above the percentage increases set out in national collective agreements. The wage drift guarantee meant that extra increases were allocated to sectors where wages were lower or had experienced less drift (Pontusson and Swenson, 1996, p. 233). By the mid-1960s, white-collar union organizations ceased following the lead of the LO-SAF agreement, asking instead for higher increases and a wage drift guarantee allowing them to be compensated for the drift that had augmented the wages of blue-collar workers. The formula for compensating

\footnotetext{
${ }^{11}$ In Sweden many low-paying service jobs, i.e. in hotel and restaurant sectors, are classified as blue-collar.
} 
white-collar workers for wage drift was a major source of contention between the LO and the PTK (Privattjänstemannakartellen), the private sector white-collar negotiating cartel. The LO disputed the claims of the white-collar organizations to wage development guarantees on the grounds that such guarantees had been conceived to protect the lowest paid segment of blue-collar workers and reward unpredicted productivity and thus it was inappropriate to apply them to higher paid white-collar workers. The leadership of the LO both publicly condemned the white-collar organizations for their compensation policy and took action to improve relative wages of blue-collar workers. In a speech to the SAP, one LO leader, Arne Geijer implied that white-collar organizations:

should keep their demands and increases in line with the limited increases that skilled blue-collar workers got out of the LO-SAF agreements. Instead they had oriented their demands to average increases for all blue-collar workers. (Swenson, 1989, p. 88)

The LO further argued that, if the members of the PTK received compensation for blue-collar wage drift, then blue-collar workers should be compensated for the individual merit increases received by white-collar workers (Olsson, 1991).

The organization boundaries of union confederations also appear to have shaped reference points of individual workers. In a comparative analysis of survey research in Britain and Sweden, Scase (1977, p. 119) notes that when bluecollar workers were asked about their relative position in the wage distribution and to identify individuals 'better off than workers like yourself', Swedish workers were more likely to refer to non-manual, white-collar workers in their responses than British workers. Scase concludes that, 'Swedish workers ... articulated a greater frequency of relative deprivation and this seems to have been a consequence of their adoption of more broadly based reference groups, incorporating both non-manual and manual occupations' (1977, p. 121). The structure of the Swedish labour movement seems to have politicized the issue of wage differentials throughout most of the period of egalitarian bargaining practices.

Despite the different views among white- and blue-collar organizations about appropriate formulas for relative wage increases, there was a brief period in 1977 and 1978 when the LO and the PTK coordinated their actions and submitted common wage demands to the SAF. This collapsed in 1980, when key divisions emerged on the question of fair distribution of wages, and wage restraint for white-collar workers (Olsson, 1991). Without an agreement on a reference point for wage differences, such as the integrated industry-wide wage scales in Italy, the subject of differentiating wage increases was the source of regular contention: each group recurrently sought to be compensated for relative gain of the other. As one author put it: 'the LO committed a colossal blunder when it did not 
seek to accommodate white-collar organizations within it' (Johnston, 1981 as cited in Fulcher, 1991, p. 206).

In 1981, the 'Action Program', adopted by the 1981 Congress of the LO-affiliated Swedish Metalworkers' Union, Metall (Svenska Metallarbetareförbundet), which had one of the largest proportions of high-skilled workers among blue-collar conferederations, revealed the membership's dissatisfaction with low-wage differentials. The 1981 Metalworkers' Union report, The Value of Work, Action Program, states:

the wage differences within the LO-collective have become so small that further evening out will no longer lead to decreased income disparity in the whole of society. The equalization policy should continue but it has to embrace all wage-earner groups. (cited by Lash, 1985, p. 222)

In other words, the entire Congress agreed that the combination of strong egalitarian provisions and the fact that such provisions were not applied to all segments of the workforce (white- and blue-collar workers) posed serious problems. Indeed, wage differentials among blue-collar workers in the metalworking sector declined substantially in the 1970s. As highly skilled blue-collar workers saw their wages being held back so as to grant greater increases to lower-skilled blue-collar workers, their relative wages fell, not only relatively to median-paid blue-collar workers, but also in relation to those of white-collar workers performing very similar work. According to field research by Lash, LO officials have argued that many workers in the blue-collar metalworking union were 'more concerned about the deterioration of their relative wages versus highly paid white-collar workers than about differentials between themselves and less favourably placed manual workers' (Lash, 1985, p. 235).

For employers, centralized bargaining no longer provided the intended benefits: wage costs were mounting exponentially, as blue-collar organizations appeared more focused on keeping pace with wage developments among whitecollar workers than exercising restraint. Moreover, employers were dissatisfied with the extensive distributional parameters contained within the wage agreements, which had evolved far beyond the equalization of wage developments across sectors. As Fulcher (1994, p. 205) summarizes: 'paradoxically, it was the SAF, ... that imposed central bargaining on unions in the 1950s but the labour movement then hi-jacked this institution, turning it into an instrument of equalization, a means of implementing the LO's long-held wages solidarity policy'.

In December 1982, the 1983 wage round began like many others. LO presented its formal wage demands to SAF, after having submitted them to the LO's council in November. However, negotiations stalled after the SAF 
delivered a 'zero-level proposal' offering only to negotiate about non-wage matters, a proposition rejected by the LO. At that point, the engineering (or metalworking) employers' association (Sveriges Verkstadsförening, VF), a main proponent of decentralizing bargaining practices, acted swiftly in order to conclude a separate, industry-level wage agreement in the metalworking sector. The VF invited Metall to break off from the central agreement and negotiate an industry-wide agreement, offering several concessions on non-wage issues (holiday wages) that Metall had pursued for a number of years. The VF thus proposed an agreement that offered more than the LO's opening demands presented the previous December (Olsson, 1991; Pontusson and Swenson, 1996; Mahon, 1999). As De Geer (1992, p. 144) explains, 'in VF's view it was more important to break the series of central negotiations to escape on this occasion with a slightly smaller increase in costs'.

The VF-Metall industry-wide contract was thus settled. It did not contain any of the low-pay provisions found within national frame agreements of the previous years (Lash, 1985; Hibbs and Locking, 2000). The internal distribution of wage increases did not parallel other previous agreements. As Swenson (1989, p. 172) explains, 'metalworkers received higher-than-average contractual increases-distributed internally in a less egalitarian fashion than in the past'.

Shortly after the VF-Metall agreement was signed, the LO and SAF signed a peak-level agreement for the remaining industries outside of the metalworking sector. The LO-SAF agreement was very similar to that of Metall and VF in that the strongest low-wage provisions were not included. By the 1990s, wage agreements were struck at the industry level, absent of the numerous egalitarian provisions in previous centralized agreements.

Employers in Sweden were able to exploit asymmetries within egalitarian institutions to break away from the agreement with the explicit goal of reversing the actively egalitarian wage policies by targeting highly skilled blue-collar workers who were receiving lower wages than their similarly skilled white-collar counter parts. As Fulcher (1991, p. 206) argues: the growth of white-collar federations constituted 'powerful obstacles to its [the LO's] wage solidarity policy'. In particular, the asymmetric application of egalitarian measures across union confederations appears to have posed a serious problem to the sustainability of actively egalitarian policies in Sweden. The Swedish experience stands in stark contrast to the case of Italy, where employers' threats to abandon egalitarian institutions and protest by some high-skilled workers did not ultimately lead to the dismantling of egalitarian bargaining institutions. In Italy, employers did not have an ally for the dismantlement of egalitarian institutions, despite some discontentment among higher-skilled workers. 


\section{Institutional remnants}

\subsection{Italy}

The driving force underlying the 1993 Protocol was to reformulate bargaining institutions so as to reduce rampant inflation. The new bargaining structures were geared towards controlling inflation and the restructuring did not include deliberate measures to counteract the heavy cumulative egalitarian effect of the preceding flat-rate indexation payments.

The combined effect of the 1992 and 1993 agreements was to replace the previous nation-wide egalitarian indexation mechanism (scala mobile) with measures to compensate for the effects of inflation within industry-wide agreements and to further delineate the respective roles of first- and second-level bargaining (sectoral and company-level bargaining). Through sectoral bargaining, basic wage rates (contractual minimums) are increased in line with inflation, based on bi-annual tripartite calculations. Industry-wide increases were not permitted to exceed the 'programmed' or predicted inflation rate ${ }^{12}$ nor reflect overall increases in productivity within the industry, as all productivity-related increases were to be allocated through firm or territorial bargaining. The 1993 agreement thus formally established 'a new architecture of nested collective bargaining' (Baccaro, 2003, p. 688), which was formally approved by workers through workplace assemblies and a binding referendum organized by the union confederations. $^{13}$

According to the new bargaining structure, the differentiation of wage increases between different skill-categories occurs through the following mechanism: each industry employs their respective wage scales to raise the wage minima of each skill-level category (inquadramento) by an approximately equal percentage. ${ }^{14}$ Firms are thus obliged to allocate the industry-wide pay increases to all workers, following the distributional parameters of the industry contracts (CCNL). As Molina and Rhodes (2007, p. 819) explain, these contracts function 'by fixing occupational scales within each sector'.

This seemingly neutral policy in fact has a rather egalitarian impact. For higher-skilled workers, the contractual minimum for their skill-category is

\footnotetext{
${ }^{12}$ In 2009, the Accordo interconfederale 15 aprile 2009 replaced the programmed inflation rate with a provisional rate based on the Harmonised Index of Consumer Prices (excluding imported energy costs) (Pedersini, 2009; Confindustria, 2010).

${ }^{13}$ Previous research on the Italian case has underlined the important role of this democratic process in solidifying support for new bargaining structures and minimizing dissent from a minority of workers (whereby objections concerned not issues of pay inequality but procedural matters of elections of representatives at the plant-level) (Baccaro, 2000; Baccaro, 2002).

${ }^{14}$ In reality, the procedure is slightly more complicated (CNEL, 1990-2004; Federmeccanica, 2002).
} 
generally a smaller percentage of their total wage than it is for lower-skilled workers (as the individually bargained component of their wages, superminimi, tends to be more substantial). Thus, not all workers receive an equal percentage increase in relation to their total wage through industry-level bargaining. For instance, in industry-bargaining in the metalworking sector, in a typical year, 1995, the wage increase for a manager (a member of the quadri) was $1.25 \%$ and that of a blue-collar worker classified in one of the lower-wage categories (level 3) was almost double (2.24\%), as Table 3 illustrates.

The outcomes of these industry-wide negotiations have not appeared controversial: their function is simply to grant increases as an equal percentage increase of the contractual wage minima designated by the wage scale. In this context, wage scales seem to act as a 'reference point' for skill-based pay differentials. Work in experimental economics has highlighted that the presence of a 'reference point' impacts individuals' perceptions of a negotiation outcome, since individuals tend to perceive outcome as a gain or a loss relative to a neutral reference point (Kahneman and Tversky, 1979, p. 274). As such, one might also gauge relative or distributional outcomes according to a reference point, where one exists (i.e. did I receive a higher, lower or equal wage increase relative to other workers?). ${ }^{15}$ Where wage scales set wage minima for an extensive range of skilllevel classification categories, the scales have the potential to formulate a neutral reference point for skill-level differences. Negotiation outcomes that echo the degree of dispersion set out in the wage scales are generally perceived as distributionally neutral and uncontroversial. Thus they are generally replicated within firm-level negotiations and only barely counter-balanced through supplemental individualized pay increases.

Under the framework set out by the 1993 Protocol, second-level bargaining (firm or company bargaining) primarily involves negotiations over qualitative issues such as hours and organization of production. With regard to pay, these negotiations are purely supplemental to the industry-level contracts, allocating pay increases based on a rise in company productivity. There are very few centralized restrictions on the distribution of firm-level increases: firms are not prevented from 'designing idiosyncratic pay structures' (Regalia and Regini, 2004, p. 81). Firm-level negotiators, usually workers at the firm and not career negotiators, often make use of the wage scale as a distributional reference point in the distribution of wage increases at the firm-level. In the Italian metalworking sector for instance, before 1993, between 36 and 59\% of firms utilized the distributional parameters from the industry-wide wage scale in order to distribute

\footnotetext{
${ }^{15}$ Elster (1989) previously found that 'wage relativities' may be illuminated by examining the concept of reference points, however, this work did not study how bargaining institutions may set reference points that differ from the status quo of actual wages.
} 
Table 4 Wage ratios in the Italian metalworking sector (inquadramento level 7/inquadramento level 3)

\begin{tabular}{llll}
\hline Year & $\begin{array}{l}\text { Ratio of annual increases in } \\
\text { minimum contractual pay for } \\
\text { a given inquadramento }\end{array}$ & $\begin{array}{l}\text { Ratio of annual 'variable' } \\
\text { increases (firm-level and } \\
\text { individual level) }\end{array}$ & $\begin{array}{l}\text { Wage ratio } \\
\text { (total wages) }\end{array}$ \\
\hline 1995 & 1.63 & 0.93 & 2.05 \\
2001 & 1.77 & 1.38 & 2.03 \\
2007 & 1.74 & 1.21 & 1.93 \\
\hline
\end{tabular}

Notes: Ratio of wages in the highest and lowest skill categories for which there is consistent data over time. Source: Federmeccanica, 'Indagine annuale sull'industria metalmeccanica' (various years).

firm-level pay increases (Federmeccanica, 2002). In line with the use of fairly egalitarian measures for deciding wage increases within firm-level bargaining in Italy, Dell'Aringa and Pagani (2007) found that in companies where firm-level bargaining takes place, 'wages are less dispersed ... in the low part of the wage distribution' (p. 41). Estimates from the Bank of Italy indicate that second-level bargaining covers around $40-45 \%$ of workers in services and industry, respectively, though other estimates are lower (Tajani, 2009).

Reports indicate that the frequency and scope of third-level bargaining, negotiations over individual, performance-based increases (superminimi), has risen in recent years, especially for higher-skilled workers (Bucalossi, 2009). As one might expect in an era experiencing an overall increase in the demand for higher-skilled workers, company-based and individual wage components have certainly risen more sharply for higher-skilled (level 7) workers, as shown in Table 4. Nonetheless, individual, performance-based increases received by high-skilled workers often only barely counter-balance the fact that only a portion of the individual's total wage has been adjusted for inflation: the collectively negotiated wage increase amounts are calculated based on the wage minima (which may be half or two-thirds of their total salary). As such, only a minority of high-skilled workers is systematically compensated for the egalitarian tendencies of industrywide negotiations.

While the striking elements of actively egalitarian wage bargaining institutions were terminated, such as the scala mobile's 'equal increases for all', key institutional remnants have been carried forward and continue to anchor the wage developments of high- and lower-skilled workers, even in the current period of increased demand for higher-skilled workers. Pay structures in Italy have continued to be based on two core components: (a) contractual minima set by wage scales, which increase in line with inflation and (b) other additional amounts stemming from firm-level and individual-level negotiations, not necessarily protected from the effects of inflation. Even the increases in individualized pay for 
high-skilled workers have not appeared to offset Italy's fairly stable and relatively egalitarian distribution of wages (Checchi and Pagani, 2005; Molina and Rhodes, 2007; Federmeccanica, 2008; Oliver, 2008).

Union leaders are aware that the subject of wage differentials might be divisive to their confederations and they have tended to avoid initiating debates on such questions. When asked about possible changes to reverse the cumulative egalitarian effects of the highly egalitarian indexation of the scala mobile, many union leaders responded that to adjust the mechanism for inflation compensation (industry-wide bargaining) in such a way as to favour the better paid is not a priority of the union and underline that the third-level of bargaining (individual) exists to provide for additional skill-level premiums. ${ }^{16}$ Furthermore, many highskilled workers indicated that they did not expect their union federation to become deeply engaged with the issue of wage differentials as the subject was handled adequately through individual performance-based wage increases. ${ }^{17}$

The multi-tiered bargaining structure, based on industry-wide pay scales, has been recently renewed with the interconferedal agreement (Accordo interconfederale 15 aprile 2009), ${ }^{18}$ which modified a number of technical dimensions of collective bargaining practices, yet explicitly re-affirmed the central role of industry-level bargaining CCNL-contracts and the two-level bargaining system established through the July 1993 accord (Ichino, 2009; Pedersini, 2009; Confindustria, 2010).

\subsection{Sweden}

In Sweden, wage agreements after 1983 were less restrictive: they did not contain obligatory distributional parameters (low-wage pots) and allowed for greater flexibility in the allocation of wage increases at the local level. As Pontusson and Swenson (1996, p. 230) describe:

wage increases after 1983 were different from those before-the peak level settlements of 1985-1986 and 1991 focused on aggregate wage increases, omitting customary details about the distribution of wage increases within sectors and firms.

This change reflected the explicit objective of the employer's association. Myrdal (1991, p. 202), from the employer's association, explained that SAF's goal after

\footnotetext{
${ }^{16}$ Interviews with a number of union leaders from the metalworking, chemical, construction and banking industries and the national confederations, which took place in the period from January to May 2003.

${ }^{17}$ Interviews with high-skilled workers in the metalworking and the chemical industries from the CISL and CGIL, April 2003.

${ }^{18}$ Signed by Confindustria, CISL and UIL in April 2009.
} 
1983 was to pursue wage policies that were more closely aligned with market demands:

SAF disagrees with wage formation being regarded as mainly a means for central collective decisions on how to distribute the total wage sum among different groups in society.... Collective agreements at industry level must therefore be flexible enough to give wide room for adaptation within companies.

In fact, in January 1990, SAF announced that it would no longer participate in nationally centralized bargaining (Freeman and Gibbons, 1995) and closed the department reponsible for bargaining (Pontusson and Swenson, 1996). SAF dissolved in 2001 when it joined the Federation of Swedish Industries to form a new association, the Confederation of Swedish Enterprise (Svenskt Näringsliv), equipped to engage in industry-level but not peak-level bargaining.

After the dismantling of centralized bargaining institutions, the procedure for increasing wages in Sweden has consisted of a series of industry-wide agreements, separate for blue-collar, white-collar and professional workers, which specify the overall increase in the total wage bill. These negotiations are followed by firmlevel negotiations, charged with the distribution of such increases. As such, as Lovén (2009, p. 1) points out:

industry-wide agreements provide leeway for company agreements on the differentiation and individualisation of wages. In this way, parts of the centrally agreed wage increase are distributed at local level according to the preferences of the local actors.

This procedure is notably different from that in Italy where industry-level bargaining establishes a minimum increase amount to be distributed to each skilllevel category, an amount which may not be altered in firm-level negotiations.

In the late 1990s, a long-term initiative for inter-sectoral coordination was launched among unions within the industrial sector as they began to cooperate more closely and engage in regular discussion on matters of industrial and skill development and pay negotiations. In 1997, industrial branches from the LO, TCO and SACO in the chemical, industrial, metalworking, food, wood and paper sectors signed the 'Cooperation Agreement on Industrial Development and Wage Formation'. The agreement, known as the Industrial Agreement, aimed to accelerate the pace of negotiations and ensure that new agreements were signed before former ones expired. Wage bargaining continued to take place at the sectoral level: the Industry Committee supervises and coordinates agreements of signatory unions though it cannot impose a settlement (Nilsson, 2001; Elvander, 2002). 
Despite this framework for coordination, several union leaders of white- and blue-collar organizations within the Industrial Agreement have noted that negotiations entail repeated conflicts on the question of wage differences between the two occupational categories. Negotiations have exhibited attempts on behalf of union negotiators to provide slightly larger increases to blue-collar workers: the 2001 metalworking agreement granted a 7\% pay rise to blue-collar workers and a $5.5 \%$ baseline increase to white-collar/professional workers (with possibility of a greater percentage in local negotiations) and the 2004 industry agreements yielded an average negotiated increase of 7.45 and $5.3 \%$ pay rise to blueand white-collar workers, respectively (Berg, 2004). Nonetheless, these egalitarian measures are on the one hand fairly controversial and on the other hand not systematically applied within firm-level allocations of industry-wide negotiations. A number of union leaders indicated that such conflicts threaten the sustainability of any coordinating arrangements. Specifically, in 2003, one of the negotiators from the former LO union, Industrifacket, the Industrial Workers' Union $^{19}$ acknowledged that larger increases for white-collar workers might cause problems for continued coordination between white- and blue-collar organizations, especially during periods of high wage growth. Meanwhile, leaders of white-collar organizations were quick to point out that many white-collar workers did not consistently receive larger nominal increases than blue-collar workers and some went as far as to say that it was not sustainable for blue-collar workers to consistently receive higher negotiated wage increases than white-collar workers. ${ }^{20}$

Despite the coordination that occurs within industry-wide bargaining, such negotiations only formulate the total percentage increase in the wage bill for blue- and white-collar workers in a given sector: it is at the company level that these increases are distributed, with entirely different criteria and procedures for increasing the wages of blue-collar workers compared with those of workers in white-collar or professional unions. As Nilsson (2001, p. 270), from the metalworking union explained: 'to an increasing extent blue-collar and whitecollar unions now collaborate closely in negotiations.... The provisions governing pay increases are, however, somewhat different'.

For most blue-collar workers, wage increases are not set on an individual basis, but are rather negotiated as a general percentage based on the firm's productivity, with few workers receiving additional increases. Selected low pay provisions have been included within LO agreements, such as the 2003 agreement for municipal workers and the minimum increases established in the 2004 industrial

\footnotetext{
${ }^{19}$ In 2006, the blue-collar Industrial Labour Union (Industrifacket) merged with Metall to form IF-Metall (Svenska Metallindustriarbetareförbundet).

${ }^{20}$ Interviews, Industrifacket, Metall, CF and SIF, SACO, Stockholm, May to June 2003.
} 
agreements (Berg, 2004). Such low-pay provisions lower wage dispersion among blue-collar workers, but do not affect the divergence between blue- and whitecollar workers.

Negotiations over wage increases for most professional and white-collar workers are more individualized and follow a distinct procedure and logic. The wage increases negotiated at the industry-level tend not to constrain individual negotiations where issues such as career trajectory tend to prevail. As noted in a report describing wage costs within the 2001 metalworking agreement: 'whitecollar workers, although fewer in number, have higher salaries to start and greater possibilities to receive an extra pay rise in local negotiations' (Berg, 2001, p. 1). A report on job classification from the 1960s still aptly summarizes the situation for white-collar workers in the private manufacturing sector: 'salaries are not in any way based on standard rate systems, salary progression curves or similar systematic means' (Samuelsson, 1966, p. 14).

Based on interviews, it appears that the goal of white-collar unions is to consistently take into account the career stage of the worker so as to follow a 'life path' of career development. An official from CF (Sveriges Civilingenjörsförbund), the SACO-affiliated Swedish Association of Graduate Engineers ${ }^{21}$ specified that a worker of 39 years of age should be receiving a $6 \%$ increase if the baseline is $2 \%$. Several other white-collar union officials from SIF, the TCO-affiliated whitecollar union $^{22}$ also indicated that their goal was to attain particularly high increases for workers in the early and mid stages of their careers in order to provide a sufficient wage basis for pension calculations. A 2008 study of SACO members found that recent growth in wage dispersion within this group stemmed from the fact that 'wage-setting focuses on individual characteristics and not only on jobs' (Granqvist and Regnér, 2008, p. 502).

The overall absence of specific distributional parameters anchoring white- and blue-collar wage developments in local negotiations appears to have allowed for a growing wage divergence between the two occupational groups in recent decades. A 2005 LO report found that the gap between blue-collar and white-collar wages was growing larger over time and noted that on an average, blue-collar workers were paid 34\% less than white-collar workers in 1994 and 43\% less in 2004 (Berg, 2005). Furthermore, data from the National Mediation Office (MI), indicates that between 1993 and 2008, the average wage increases for white-collar workers in all industries of the private sector were greater than those of private sector bluecollar workers for every year except for 1995, 1997, 2007, 2008. ${ }^{23}$ As Figure 3

\footnotetext{
${ }^{21}$ Now Sveriges Ingenjörer (SI).

${ }^{22}$ Now Unionen.

${ }^{23}$ The increases were identical in $2006(3.1 \%)$.
} 


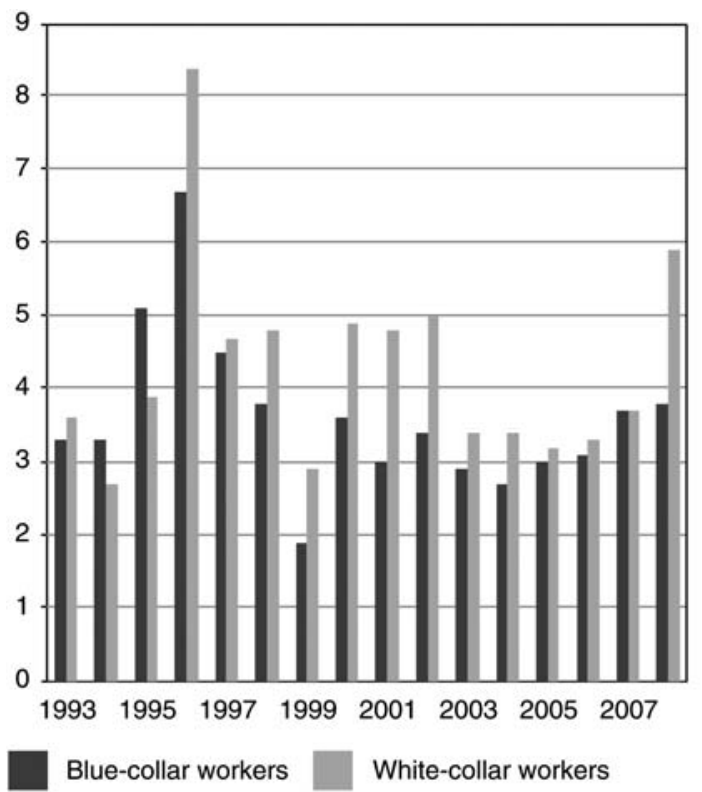

Notes: Data refer to average increases for a given group in the private sector.

Source: National Mediation Office Wage Statistics - Yearly Changes 1993-2008, based on data from Statistics Sweden; accessed at www.mi.se/inenglish/menu_eng_wage_statistics.html on July 10, 2009.

Figure 3 Annual average percentage wage growth in Swedish industry.

illustrates, average wage increases in the industrial sector were higher for white-collar worker for all but 3 years. Furthermore, for industrial workers, from 1996 to 2004, average wage increases were from 17 to $60 \%$ greater for white-collar workers. It is notable that the difference in average wage increase was greater among workers in the industrial sector, despite the presence of the 'Cooperation Agreement on Industrial Development and Wage Formation'.

The primary goal of employers in the engineering industry was to reform bargaining so as to remove wage pots and other low-wage provisions, even if this meant higher over-all wage increases and as such, the bargaining practices after 1983 have contained few built-in egalitarian provisions. Furthermore, the presence of separate organizations negotiating increases for their respective occupational group, using divergent and unrelated approaches, appears to have contributed to heightening wage differentials between white- and blue-collar workers. Once widespread actively egalitarian provisions were removed from bargaining agreements, there has been little in the content of negotiations to 
penetrate local bargaining practices and uphold the high levels of wage equality attained in past periods.

\section{Conclusion}

As egalitarian institutions and policies are being rolled back across advanced industrial democracies, this work suggests that such outcomes are best understood when not grouped into a single category. In spite of the eclipse of widespread actively egalitarian institutions, remnants of these institutions persist and continue to root social solidarity within institutional frameworks. However, such remnants vary tremendously across countries and continue to diverge with regard to how wage differences are conceptualized, negotiated and applied. This paper argues that diverging paths in Italy and Sweden have been partly due to the fact that the two countries had very different collective bargaining foundations on which the egalitarian components were layered. Italy already had detailed wage scales for both blue- and white-collar workers and union confederations that encompassed all skill levels. Sweden, on the other hand, had only wage scales for blue-collar workers, and white- and blue-collar workers were organized in separate union confederations. These core structural differences shaped the politics and possibilities surrounding questions of wage differentials at a number of different stages, including that which followed the phase of actively egalitarian wage bargaining.

Egalitarian policies themselves were the product of widespread movements favouring greater protection for lower paid workers, and were developed in the midst of other social demands in each country. Certainly, confederal groupings and wage scales cannot be said to have caused expansive egalitarian policies in Italy and Sweden. However, these institutions, as the building blocks upon which egalitarian provisions were constructed, affected not only the sort of egalitarian institutions that emerged, but also their sustainability in the face of contestation. Egalitarian measures for blue-collar workers in Sweden were never directly applied to workers in white-collar or professional unions, while in Italy the full range of skill-levels was covered. When protest about egalitarian institutions emerged in each case, the type of wage scales and confederal groupings influenced the form of dissent and the ability of employers to form alliances in favour of deliberately dismantling egalitarian structures. Furthermore, the ways in which dismantlement unfolded appear to have influenced the extent to which important institutional remnants were carried forward and integrated within the superseding institutional structures.

In Italy, fundamental modifications to the bargaining structure in 1992 and 1993 integrated constituent elements of the egalitarian bargaining within the new framework. The bargaining system has continued to include a contractual 
minimum, set within a common scale for white- and blue-collar workers, as the basis for sectoral wage negotiations and as the wage component that is compensated for inflation. Union organizations continue to encompass multiple skilltypes and industry-level bargaining structures, with linked outcomes for lowerand higher-skilled workers. The combined and interactive effects of these union organizations and structures have yielded outcomes, which might not have been possible to achieve through explicit calls for solidarity. The result has been rather stable wage differentials amidst a background of rising individual pay components for higher-skilled workers.

In Sweden, there have been impressive coordination schemes, where whitecollar and professional unions have agreed to smaller percentage increases in their wage bills than those received by blue-collar workers. Yet unlike in Italy, in the wake of actively egalitarian policies, few institutional remnants were carried forward. The important 'low wage pots', which defined the era of egalitarian centralized bargaining, are no longer a part of wage bargaining institutions. Moreover, as was the case in the past during centralized bargaining, measures implemented by the LO only apply to LO workers. Thus despite the coordination between white- and blue-collar workers that mildly favoured lower skilled workers, wage differences have risen fairly consistently. Without widespread wage scales, subsequent local negotiations allow for great flexibility in the distribution of pay increases and often heavily favour high-skilled white-collar workers. Thus, while an organization devoted to lower-wage workers may able to be more vocal about the challenges faced by this group, it lacks the silent leverage of an organization that encompasses a broad range of skill-groups.

\section{Data appendix}

Data from the OECD 'Structure of Earnings' data set is somewhat problematic for comparing the cases of Italy and Sweden. The OECD data set includes government workers for all countries, with the exception of Italy. Second, the original data set includes data for Sweden covering over three decades; for Italy, it only contains data from 1985 to 1996. However, I was able to access the original data set from which the figures on Italy within OECD's data set were acquired, the Istituto Nazionale Previdenza Sociale (INPS) data set, at LABORatorio R. Revelli, and Dott. Villisio provided the exact extraction code used in the assembly of the OECD data set. This made it possible to calculate 90:10 earnings inequality figures that include both private sector and government workers and extend from 1985 to 1999. Further details of these calculations are available on a supplementary material web appendix. ${ }^{24}$

\footnotetext{
${ }^{24}$ Available at http://www.units.muohio.edu/politicalscience/user/29.
} 


\section{Acknowledgements}

I thank Christopher Erickson, Andrea Ichino and Douglas Hibbs for generously sharing their data. I am grateful to Andrea Fioni, from Assolombarda, Milanese branch of the Confindustria for allowing me to access unpublished data and to Angelo Megaro from the Federmeccanica for providing data on the Italian metalworking sector. Access to the INPS data was possible thanks to the generous hospitality of the Laboratorio R. Revelli, Centre for Employment Studies, extended by Bruno Contini, where Roberto Quaranta provided invaluable guidance and Claudia Villosio generously shared existing coding. I thank Gabriele Ballarino, Pablo Beramendi, Helen Callaghan, Daniele Checchi, Stephen Hellman, Pietro Ichino, Lane Kenworthy, Margitta Mätzke, Claudia Ogriseg, Ida Regalia, Marino Regini, David Rueda, Kathleen Thelen, Peter Swenson, Juhana Vartiainen, Michael Wallerstein and the three anonymous reviews for useful discussion and valuable comments on earlier drafts.

\section{Supplementary material}

Supplementary material is available at SOCECO Journal online.

\section{Funding}

This work was supported by the Social Science and Humanities Research Council of Canada (SSHRC); and the Kellogg Dispute Resolution Research Center (DRRC) at Kellogg Graduate School of Management, Northwestern University.

\section{References}

Accornero, A. (1992) La parabola del sindacato: Ascesa e declino di una cultura, Bologna, il Mulino.

Atkinson, A. B. (2008) The Changing Distribution of Earnings in OECD Countries, New York, NY, Oxford University Press.

Baccaro, L. (2000) 'Centralized Collective Bargaining and the Problem of "Compliance": Lessons from the Italian Experience', Industrial and Labor Relations Review, 53, 579-601.

Baccaro, L. (2002) 'The Construction of "Democratic" Corporatism in Italy', Politics and Society, 30, 327-357.

Baccaro, L. (2003) 'What is Alive and What is Dead in the Theory of Corporatism', British Journal of Industrial Relations, 41, 683-706.

Baccaro, L. and Locke, R. (1996) The End of Solidarity? Union Fragmentation and the Decline of Egalitarian Wage Policies in Italy and Sweden, Unpublished manuscript, later published in 1998 in the European Journal of Industrial Relations. 
Baccaro, L. and Locke, R. (1998) 'The End of Solidarity? The Decline of Egalitarian Wage Policies in Italy and Sweden', European Journal of Industrial Relations, 4, 283-308.

Baccaro, L., Carrieri, M. and Damiano, C. (2003) 'The Resurgence of the Italian Confederal Unions: Will it Last?', European Journal of Industrial Relations, 9, 43-59.

Baglioni, G. (1980) Analisi Della Cisl, Roma, Edizioni Lavoro.

Bardone, L., Gittleman, M. and Keese, M. (1998) 'Causes and Consequences of Earnings Inequality in OECD Countries', Lavoro e relazioni industriali, 2, 13-58.

Bedani, G. (1995) Politics and Ideology in the Italian Workers' Movement, Oxford, Berg Publishers.

Begamaschi, M., Zanette, E. and Martini, E. (eds) (1980) Salari contrattuali e piattaforme rivendicative dei metalmeccanici, 1948-1979, Milano, Franco Angeli Editore.

Berg, A. (2001) 'Engineering Pay Deal Agreed', European Foundation for the Improvement of Living and Working Conditions, Eurofound, Dublin, EIRO online, accessed at http://www.eurofound.europa.eu/eiro/2001/02/feature/se0102182f.htm on September 21, 2010.

Berg, A. (2004) 'First Agreements in 2004 Bargaining Round Concluded in Industry', European Foundation for the Improvement of Living and Working Conditions, Eurofound, Dublin, EIRO online, accessed at http://www.eurofound.europa.eu/eiro/2004/03/ feature/se0403103f.htm on September 21, 2010.

Berg, A. (2005) 'Gap between Blue-Collar and White-Collar Pay Increases', European Foundation for the Improvement of Living and Working Conditions, Eurofound, Dublin, EIRO online, accessed at http://www.eurofound.europa.eu/eiro/2005/10/ feature/se0510102f.htm on September 21, 2010.

Berman, E., Bound, J. and Griliches, Z. (1994) 'Changes in Demand for Skilled Labor within U.S. Manufacturing: Evidence from the Annual Survey of Manufacturers', The Quarterly Journal of Economics, 109, 367-397.

Brandolini, A., Cipollone, P. and Sestito, P. (2001) Earnings Dispersion, Low Pay and Household Poverty in Italy, 1977-1998, Roma, Banca D’Italia.

Bucalossi, G. (2009) 'Italy: "Wage Formation”', European Foundation for the Improvement of Living and Working Conditions, Eurofound, Dublin, EIRO online, accessed at http://www.eurofound.europa.eu/eiro/studies/tn0808019s/it0808019q.htm on September 21, 2010.

Carniti, P. (1977) L'autonomia alla prova: Il sindacato italiano negli anni della crisi, Roma, Coines Edizioni.

Carinci, F. (1987) 'L'evoluzione storica', Quaderni di diritto del lavoro e delle relazioni industriali, 6 (special issue 'Inquadramento dei lavoratori'), 12-39.

Cella, G. P. (1989) 'Criteria of Regulation in Italian Industrial Relations'. In Lange, P. and Regini, M. (eds) State, Market and Social Regulation: New Perspectives on Italy, Cambridge, Cambridge University Press, pp. 167-186. 
Cella, G. P. and Treu, T. (1998) 'La contrattazione collettiva'. In Cella, G. P. and Treu, T. (eds) Le nuove relazioni industriali: L'esperienza italiana nella prospettiva europea, Bologna, il Mulino, pp. 183-246.

Cella, G. P., Manghi, B. and Piva, P. (1977) Un sindacato italiano negli anni sessanta: La FIM-CISL dall'associazione alla classe, Bari, De Donato.

Checchi, D. and García-Peñalosa, C. (2008) 'Labour Market Institutions and Income Inequality', Economic Policy, 23, 601-646.

Checchi, D. and Pagani, L. (2005) The Effects of Unions on Wage Inequality: The Italian Case in the Nineties, Bonn, Institute for the Study of Labor (IZA), pp. 43-70.

CNEL, C. N. d. E. e. d. L. (1990-2004) 'Contratti correnti', accessed at http://www. portalecnel.it/portale/ArchivioContrattiOnLine.nsf/vwPerSettoreContratto?Openview on September 21, 2010.

CNEL, C. N. d. E. e. d. L. (1990-2004) 'Archivio Nazionale dei Contratti Collettivi di Lavoro'. Consiglio Nazionale dell'Economia e del Lavoro, Roma, accessed at http:// www.portalecnel.it/Portale/Homepagesezioniweb.Nsf/Vwhp/Archiviocontrattien? Opendocument\&Lang=En.

Confindustria (2010) Collective Bargaining Reform Package, Rome, Confindustria.

De Geer, H. (1992) The Rise and Fall of the Swedish Model, Chichester, Carden Publications and the FA Institute.

Dell'Aringa, C. (1994) 'Wage Dispersion and Unionism: Do Unions Protect Low Pay?', International Journal of Manpower, 15, 150-169.

Dell'Aringa, C. and Pagani, L. (2007) 'Collective Bargaining and Wage Dispersion in Europe’, British Journal of Industrial Relations, 45, 29-54.

Ebbinghaus, B. and Visser, J. (2000) The Societies of Europe: Trade Unions in Western Europe since 1945, Oxford, MacMillan Reference Ltd.

Edgren, G. (1966) 'The Role of the Job Classification System in Implementing TCO Wage Policy. TCO International Seminar at Gallofsta, Sweden'. In TCO (ed) Job Classification and Collective Bargaining: TCO International Seminar at Gallofsta in Sweden, June 6-10, 1966, Stockholm, TCO, pp. 5-13.

EIRR (1990) 'Industrial Relations in Turmoil', European Industrial Relations Review, 199, $10-14$.

Elster, J. (1989) The Cement of Society: A Study of Social Order, New York, NY, Cambridge University Press.

Elvander, N. (2002) 'The Labour Market Regimes in the Nordic Countries: A Comparative Analysis', Scandinavian Political Studies, 25, 117-137.

Erickson, C. and Ichino, A. (1994) 'Wage Differentials in Italy: Market Forces, Institutions and Inflation'. In Freeman, R. B. and Katz, L. M. (eds) Differences and Changes in Wage Structures, Chicago, IL, University of Chicago Press, pp. 265-306.

Faustini, G. (1976) 'Wage Indexation and Inflation in Italy', Banca Nazionale del Lavoro Quarterly Review, 29, 364-377. 
Federmeccanica (2002) Ventiseisima indagine annuale sull'industria metalmeccanica, Roma, Federmeccanica.

Federmeccanica (2008) Indagine annuale sull'industria metalmeccanica, Roma, Federmeccanica.

Forsebäck, L. (1980) Industrial Relations and Employment in Sweden, Stockholm, Swedish Institute.

Freeman, R. B. and Gibbons, R. S. (1995) 'Getting Together and Breaking Apart: The Decline of Centralized Collective Bargaining'. In Freeman, R. B. and Katz, L. F. (eds) Differences and Changes in Wage Structures, Chicago, IL, University of Chicago Press, pp. 345-370.

Fulcher, J. (1991) Labour Movements, Employers and the State, New York, NY, Oxford University Press.

Fulcher, J. (1994) 'The Social Democratic Model in Sweden: Termination or Restoration?', The Political Quarterly, 65, 203-213.

Ginsborg, P. (1990) A History of Contemporary Italy, London, Penguin Group.

Golden, M. (1988) Labor Divided: Austerity and Working-Class Politics in Contemporary Italy, Ithaca, NY, Cornell University Press.

Granqvist, L. and Regnér, H. (2008) 'Decentralized Wage Formation in Sweden', British Journal of Industrial Relations, 46, 500-520.

Hibbs, D. A. and Locking, H. (2000) 'Wage Dispersion and Productive Efficiency: Evidence for Sweden', Journal of Labour Economics, 18, 755-782.

Ichino, P. (2009) 'Note techniche sull'accordo interconfederale del 22 gennaio', LaVoce, accessed at http://www.lavoce.info/articoli/pagina1000909.html.

Ingham, G. (1974) Strikes and Industrial Conflict, Britain and Scandinavia, London, MacMillan.

Iversen, T. (1996) 'Power, Flexibility, and the Breakdown of Centralized Wage Bargaining: Denmark and Sweden in Comparative Perspective', Comparative Politics, 28, 399-436.

Iversen, T. (1999) Contested Economic Institutions: The Politics of Macroeconomics and Wage-Bargaining in Advanced Democracies, Cambridge, Cambridge University Press.

Jonsson, L. and Siven, C.-H. (1986) Why Wage Differentials?, Stockholm, SAF’s Förlag.

Johnston, T. L. (1981) 'Sweden'. In Smith, E. O. (ed) Trade Unions in the Developed Economies, London, Croom Helm, pp. 97-122.

Kahneman, D. and Tversky, A. (1979) 'Prospect Theory: An Analysis of Decision under Risk', Econometrica, 47, 263-291.

Katz, H. C. (1993) 'The Decentralization of Collective Bargaining: A Literature Review and Comparative Analysis', Industrial and Labor Relations Review, 47, 3-22.

Kenworthy, L. (2008) Jobs with Equality, Oxford, Oxford University Press.

Kenworthy, L. and Pontusson, J. (2005) 'Rising Inequality and the Politics of Redistribution in Affluent Countries', Perspectives on Politics, 3, 449-471. 
Kitschelt, H. and Streeck, W. (2003) 'From Stability to Stagnation: Germany at the Beginning of the Twenty-First Century', West European Politics, 26, 1-34.

Kjellberg, A. (1992) 'Sweden: Can the Model Survive?'. In Ferner, A. and Hyman, R. (eds) Industrial Relations in the New Europe, Oxford, Basil Blackwell, pp. 88-142.

Kjellberg, A. (1998) 'Sweden: Restoring the Model?'. In Ferner, A. and Hyman, R. (eds) Changing Industrial Relations in Europe, 2nd edn, Oxford, Blackwell, pp. 74-117.

Kjellberg, A. (2004) Wage Tariffs, unpublished report, Lund Universitet, Sociologiska institutionen, Lund, Sweden.

Koeniger, W., Nunziata, I. and Leonardi, M. (2007) 'Labour Market Institutions and Wage Inequality', Industrial and Labor Relations Review, 60, 339-356.

Lange, P., Ross, G. and Vannicelli, M. (1982) Unions, Change and Crisis: French and Italian Union Strategy and the Political Economy 1945-1980, London, George Allen \& Unwin.

Lash, S. (1985) 'The End of Neo-Corporatism?: The Breakdown of Centralised Bargaining in Sweden', British Journal of Industrial Relations, 23, 215-239.

Locke, R. (1995) 'Eppure Si Tocca: The Abolition of the Scala Mobile'. In Mershon, C. and Pasquino, G. (eds) Italian Politics: Ending the First Republic, Vol. 9 of Italian Politics: a Review, Boulder, CO, Westview Press, pp. 185-196.

Locke, R. and Thelen, K. (1995) 'Apples and Oranges Revisited: Contextualized Comparisons and the Study of Comparative Labor Politics', Politics \& Society, 23, 337-367.

Lovén, K. (2009) Sweden: Industrial Relations Profile, European Foundation for the Improvement of Living and Working Conditions, Eurofound, Dublin, EIRO online, accessed at http://www.eurofound.europa.eu/eiro/country/sweden_4.htm on September 21, 2010.

Lungarella, R. (1981) La scala mobile 1945-1981, Venezia, Marsilio Editori.

Mahon, R. (1999) “'Yesterday's Modern Times Are No Longer Modern”: Swedish Unions Confront the Double Shift'. In Martin, A. and Ross, G. (eds) The Brave New World of European Labor: European Trade Unions at the Millennium, New York, Berghahn, pp. 125-166.

Meidner, R. (1974) Coordination and Solidarity: An Approach to Wages Policy, Stockholm, LO.

Meidner, R. and Ohman, B. (1972) Fifteen Years of Wage Policy, Stockholm, LO.

Molin, K., Amark, K. and Misgeld, K. (eds) (1988) Creating Social Democracy: A Century of the Social Democratic Labor Party in Sweden, University Park, PA, Pennsylvania State University Press.

Molina, O. and Rhodes, M. (2007) 'Industrial Relations and the Welfare State in Italy: Assessing the Potential of Negotiated Change', West European Politics, 30, 803-846.

Myrdal, H.-G. (1991) 'The Hard Way from a Centralised to a Decentralised Industrial Relations System-The Case of Sweden and SAF'. In Sadowski, D. and Jacobi, O. (eds) Employers' Associations in Europe: Policy and Organization, Baden, Nomos Verlagsgesellschaft, pp. 191-210. 
Natali, D. and Pochet, P. (2009) 'The Evolution of Social Pacts in the Emu Era: What Type of Institutionalization?', European Journal of Industrial Relations, 15, 147-166.

Nilsson, G. (2001) 'A New Swedish Model in a New Europe'. In Schulten, T. and Bispinck, R. (eds) Collective Bargaining under the Euro: Experiences from the European Metal Industry, Brussels, ETUI and EMF, pp. 259-284.

OECD (2002) OECD's Structure of Earnings, Unpublished Dataset, Paris, OECD.

OECD (2004) OECD Employment Outlook, Paris, OECD.

Oliver, R. (2008) 'Diverging Developments in Wage Inequality: Which Institutions Matter?', Comparative Political Studies, 41, 1551-1582.

Olsson, A. (1991) The Swedish Wage Negotiation System, Worcester, Dartmouth Publishing Company Limited.

Patriarca, S. (1986) La nuova scala mobile: la retribuzione dopo la riforma della contingenza e dell'Irpef, Roma, Ediesse.

Pedersini, R. (2009) Cgil Refuses to Sign Agreement on Collective Bargaining Reform, European Foundation for the Improvement of Living and Working Conditions, Eurofound, Dublin, Eiro online, accessed at http://www.eurofound.europa.eu/eiro/2009/02/ articles/it0902059i.htm on September 21, 2010.

Pérez, S. A. (2000) 'From Decentralization to Reorganization: Explaining the Return to National Bargaining in Italy and Spain', Comparative Politics, 32, 437-458.

Pontusson, J. (2005) Inequality and Prosperity: Social Europe vs. Liberal America, Ithaca, NY, Cornell University Press.

Pontusson, J. and Swenson, P. (1996) 'Labor Markets, Production Strategies, and Wage Bargaining Institutions: The Swedish Employer Offensive in Comparative Perspective', Comparative Political Studies, 29, 223-250.

Pontusson, J., Rueda, D. and Way, C. (2002) 'Comparaitve Political Economy of Wage Distribution: The Role of Partisanship and Labour Market Institutions', British Journal of Political Science, 32, 281-308.

Regalia, I. and Regini, M. (2004) 'Collective Bargaining and Social Pacts in Italy'. In Katz, H. C., Lee, W. and Lee, J. (eds) The New Structure of Labor Relations: Tripartism and Decentralization, Ithaca, ILR Press, an imprint of Cornell University Press, pp. 59-118.

Regalia, I., Regini, M. and Reyneri, E. (1978) 'Labour Conflicts and Industrial Relations in Italy'. In Crouch, C. and Pizzorno, A. (eds) Resurgence of Class Conflict in Western Europe since 1968, London, MacMillan Press, pp. 101-158.

Regini, M. (2000) 'Between Deregulation and Social Pacts: The Responses of European Economies to Globalization', Politics \& Society, 28, 5-33.

Regini, M. and Regalia, I. (1997) 'Employers, Unions and the State: The Resurgence of Concertation in Italy', West European Politics, 20, 210-230.

Rueda, D. and Pontusson, J. (2000) 'Wage Inequality and Varieties of Capitalism', World Politics, 52, 350-383. 
Samuelsson, K. O. (1966) 'The Importance of a Job Classification System from the Employers' Point of View'. In TCO (ed) Job Classification and Collective Bargaining: TCO International Seminar at Gallofsta in Sweden, June 6-10, 1966, Stockholm, TCO, pp. $14-20$.

Scase, R. (1977) Social Democracy in Capitalist Society: Working Class Politics in Britain and Sweden, London, Croom Helm, Rowman and Littlefield.

Swenson, P. (1989) Fair Shares: Unions, Pay, and Politics in Sweden and West Germany, Ithaca, Cornell University Press.

Swenson, P. (1991) 'Bringing Capital Back in, or Social Democracy Reconsidered: Employer Power, Cross-Class Alliances, and Centralization of Industrial Relations in Denmark and Sweden', World Politics, 43, 513-544.

Tajani, C. (2009) Italy: Wage Flexibility and Collective Bargaining, European Foundation for the Improvement of Living and Working Conditions, Eurofound, Dublin, EIRO online, accessed at http://www.eurofound.europa.eu/eiro/studies/tn0803019s/ it0803019q.htm on September 21, 2010.

Thelen, K. (1993) 'West European Labor in Transition: Sweden and Germany Compared', World Politics, 1, 23-49.

Traxler, F., Blaschke, S. and Kittel, B. (2001) National Labour Relations in Internationalized Markets: A Comparative Study of Institutions, Change and Performance, Oxford, Oxford University Press.

Vartiainen, J. (1998) 'Understanding Swedish Social Democracy: Victims of Success?, Oxford Review of Economic Policy, 14, 19-39.

Visser, J. (2000) 'Italy'. In Ebbinghaus, B. and Visser, J. (eds) The Societies of Europe: Trade Unions in Western Europe since 1945, London, MacMillan Reference Ltd, pp. 371-428.

Visser, J. and Checchi, D. (2009) 'Inequality and the Labour Market: Unions'. In Wiemer Salverda, B. N. and Smeeding, T. M. (eds) The Oxford Handbook of Economic Inequality, Oxford, Oxford University Press, pp. 230-256.

Visser, J. and Waddington, J. (1996) 'Industrialization and Politics: A Century of Union Structural Development in Three European Countries', European Journal of Industrial Relations, 2, 21-53.

Wallerstein, M. (1999) 'Wage-Setting Institutions and Pay Inequality in Advanced Industrial Societies', American Journal of Political Science, 43, 649-680. 